\title{
DYNAMICS OF CHANGES IN THE INDICES OF THE LEVEL OF ENDOGENOUS INTOXICATION IN PATIENTS WITH ALCOHOLIC LESIONS OF THE LIVER
}

\author{
P.S. Nazar, M.M. Levon, O.I. Osadcha, O.O. Shevchenko
}

Abstract. Changes of the indices of the level of endogenous intoxication in 122 patients with an alcoholic lesion of the liver have been studied. It has been established that a high level of endogenous intoxication is identified in these patients connected with a reduction of the concentration of endogenous albumin in the peripheral blood, due to an accumulation of molecules of medium mass, a decrease of the effective concentration of albumin and the toxin-binding ability of albumin.

Key words: hepatic alcoholic lesion, endogenous intoxication, cytolytic activity.

National University of Physical Training and Sport of Ukraine (Kyiv)

Рецензент - проф. О.І. Федів

Buk. Med. Herald. - 2013. - Vol. 17, № 1 (65). - P. 68-71

Надійшла до редакції 08.01.2013 року

(C) П.С. Назар, М.М. Левон, О.І. Осадча, О.О. Шевченко, 2013

УДК 616.233:611-018.1:616.24-002+616.24-002.5:616-07:577.17

Н.В. Обухова

\section{ВЛИЯНИЕ ЛИПОФЛАВОНА НА ОСТЕОПРОТЕГЕРИН- ОПОСРЕДОВАННУЮ ЛИМФОИДНУЮ (ЛЕЙКОЦИТАРНУЮ) РЕГУЛЯЦИЮ СИНТЕЗА ЦИТОКИНОВ КЛЕТКАМИ ЭПИТЕЛИЯ БРОНХОВ У БОЛЬНЫХ ХРОНИЧЕСКИМ ОБСТРУКТИВНЫМ ЗАБОЛЕВАНИЕМ ЛЕГКИХ, ПЕРЕНЕСШИХ ТУБЕРКУЛЕЗ ЛЕГКИХ}

ГУ "Донецкий государственный медицинский университет", г. Донецк

Резюме. У больных хроническим обструктивным заболеванием легких (ХОЗЛ), перенесших туберкулез (ТБ) легких, изучены регионарный (в индуцированной мокроте) уровень остеопротегерина, а также модулирующее влияние липофлавона на остеопротегеринопосредованную лимфоидную (лейкоцитарную) регуляцию синтеза цитокинов клетками эпителия бронхов.

Установлено, что у больных ХОЗЛ І-ІІ стадии, прежде всего - у больных, перенесших ТБ легких и с достоверно более высоким уровнем остеопротегерина в индуцированной мокроте выявлена возможность липофлавонопосредованной коррекции остеопротегерин-

Введение. К факторам, способствующим углублению цитокинового дисбаланса у больных с хроническим обструктивным заболеванием легких (ХОЗЛ) относят, в частности, перенесенный туберкулез (ТБ) легких, выступающий в качестве клинического маркера резкого снижения многочисленных защитных "барьеров" системы органов дыхания [4]. Попытки использования терапевтической "анти-TNF-стратегии" у больных ХОЗЛ, перенесших ТБ (или со скрытым ТБ), как указывают Hamdi Н. и соавт. (2006) [7], Saliu О. и соавт. (2006) [10] вскрыли главное осложнение анти-TNF-терапии - реактивацию скрытой ТБ инфекции. Так, было установлено, что под влиянием TNF-антагонистов (etanercept, infliximab, adalimumab) уменьшается субпопуляция и функциональная активность "антимикобактериальных" CD4+ T-клеток памяти, способных подавлять микобактерии путем синтеза IFN- $\gamma[7$, зависимого лейкоцитоопосредованного синтеза клетками бронхиального эпителия уровня провоспалительных цитокинов IL-1 $\beta$ и TNF- $\alpha$, цитокина IL-4 и активной формы TGF- $\beta 1$. Указанные факты расцениваются как патофизиологическое обоснование целесообразности местного (ингаляции, эндобронхиальное введение) использования у подобных больных липофлавона для коррекции дисбаланса цитокинового гомеостаза на регионарном (ткани бронхов) уровне.

Ключевые слова: остеопротегерин, цитокины, бронхиальный эпителий, хроническое обструктивное заболевание легких, туберкулез легких.

10]. В этой связи особый интерес, по нашему мнению, заслуживает использование в лечении больных ХОЗЛ, перенесших туберкулезный процесс, препаратов с антицитокиновой активностью, не относящихся непосредственно к антиTNF-препаратам.

Большое внимание исследователей, особенно в последние годы, уделяется нетоксичным полифенольным соединениям - флавоноидам, биологическая активность которых in vivo связана с их способностью опосредованно (через антиоксидантный эффект) модулировать цитокиновый потенциал, восстанавливать остеобластогенез через активацию, независимую от рецепторов эстрогена, взаимодействовать со свободными радикалами, обрывать цепные свободнорадикальные реакции, инактивировать липодиоксиды, липоксиды; изменять активность различных ферментов $[5,9]$. 
В небольшом ряду водорастворимых форм кверцетина особое место занимает липофлавон кверцетин, включенный в уникальную систему доставки - липосому. Последнее позволяет добиться: водорастворимости кверцетина; активной пенетрации кверцетина в очаг воспаления благодаря высокой биодоступности липосомальной формы доставки; синергизма эффектов кверцетина и липосомальной формы фосфатидилхолина, что сопровождается достоверным усилением антиоксидантного, цитопротекторного и эндотелийпротекторного эффекта $[1,3,6]$. В витральных экспериментальных моделях доказано, что фосфатидилхолиновые липосомы оказывают модулирующее влияние на LPS-стимулированный синтез TNF- $\alpha$, IL-1 $\beta$ и TGF- $\beta 1$ клетками эпителия бронхов больных ХОЗЛ, перенесших ТВС легких и протекающим в сочетании с анемией [2].

В свете вышеизложенного можно предположить, что дальнейший поиск методов коррекции дисбаланса цитокинового гомеостаза - важного патогенетического механизма прогрессирования ХОЗЛ, можно отнести к актуальным проблемам современной пульмонологии.

Цель исследования. Научное обоснование целесообразности использования и оценка клинической эффективности оптимизированной базисной терапии для коррекции регионарного (эндобронхиального) остеопротегеринзависимого дисбаланса цитокинового гомеостаза при хроническом обструктивном заболевании легких у лиц, перенесших ТБ легких.

Материал и методы. В настоящей работе нами представлены результаты изучения у подобных больных регионарного (в индуцированной мокроте) уровня остеопротегерина, а также модулирующего влияния липофлавона на остеопротегеринопосредованную лимфоидную (лейкоцитарную) регуляцию синтеза цитокинов клетками эпителия бронхов.

Под наблюдением состояло 83 больных ХОЗЛ (I-ІІ степени тяжести, стабильное течение), которых распределили следующим образом: в 1ю группу вошли 41 больной ХОЗЛ, 2-ю группу составили 42 больных ХОЗЛ, перенесшие различные формы ТБ легких. Контролем служили 14 здоровых лиц, у которых бронхоальвеолярные смывы получали при диагностической бронхоскопии, проводимой по поводу спорных клинических ситуаций (призывники), и у которых после комплексного обследования патологические изменения в бронхолегочной системе не выявлены.

Концентрацию остеопротегерина в индуцированной мокроте (которую собирали после многократной ингаляции гипертонического раствора хлорида натрия через небулайзер) определяли иммуноферментным методом с использованием коммерческих наборов Human Osteoprotegerin (OPG) ELISA Kit компании Biomedica Medizinprodukte $\mathrm{GmbH} \&$ Co KG (Австрия). Оценка результатов осуществлялась фотометрически.
Для культивации клеток эпителия бронхов использован метод краткосрочных органных культур, обеспечивающий культивирование клеток in vitro. Культивация проводилась в присутствии антибиотиков (бензилпенициллина натриевой соли 1000 ЕД и стрептомицина сульфата 0,01 г на 1 мл культуральной среды). Клетки эпителия бронхов получали из мокроты. Параллельно проводились несколько экспериментов, включая преинкубацию суспензии LPS-индуцированных мононуклеаров с остеопротегерином (использовался Osteoprotegerin (OPG) human, recombinant, Sigma-Aldrich, США) с последующим введением в культуральную среду при начале культивирования.

Мононуклеарные лейкоциты выделяли из гепаринизированной крови центрифугированием на градиенте плотности фиколл-верографина. LPS получали из штаммов E.coli K 30 и C 600 (lux)(R-мутанты) по методу Westphal O. (1984) [11]. Мягкий гидролиз нативного LPS проводили уксусной кислотой. Концентрацию цитокинов определяли методом твердофазного иммуноферментного анализа. Для определения TNF-a и IL-4 были использованы тест-системы и реагенты ProCon ТОО "Протеиновый контур" (Россия), уровня IL-1b - тест-системы TOO"Цитокин" (Россия). Содержание в сыворотке крови активной формы TGF- $\beta 1$ определяли методом иммуноферментного анализа с использованием тест-системы "TGF $\beta 1 \mathrm{E}_{\max }^{\circledR}$ ImmunoAssay System" (Promega, США).

Результаты исследований и их обсуждение. Накопленные в последнее десятилетие научные факты позволили сформулировать научную концепцию остеопротегеринзависимых механизмов формирования остеопенического синдрома у больных ХОЗЛ [8]. С другой стороны, у больных ХОЗЛ выявлена системнорегионарная дискретность содержания остеопротегерина: снижение в системном кровотоке, "регламентируемое" степенью тяжести заболевания, а также существенное повышение регионарного (эндобронхиального) содержания цитокина. Механизмы разнонаправленной динамики содержания остеопротегерина в общем кровотоке и in loko morbi (на уровне тканей бронхов) остаются предметом научной дискуссии [8].

При исследовании уровня остеопротегерина в индуцированной мокроте нами установлено, что в группе здоровых лиц исследованный пока-

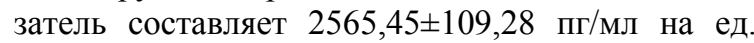
белка, а у больных 1-й и 2-й групп уровень цитокина в индуцированной мокроте повышен соответственно в 5,6 и 7,4 раза $(\mathrm{p}<0,001)$. При этом уровень остеопротегерина в индуцированной мокроте у больных 2-й группы на 32,3\% $\left(\mathrm{p}_{1}<0,001\right)$ выше, чем у больных 1-й группы. Таким образом, перенесенный ТБ легких является "фактором отягощения" риска формирования остеопенического синдрома у больных ХОЗЛ. 
Таблица

Влияние липофлавона на остеопротегерин-зависимую лимфоидную (лейкоцитарную) регуляцию синтеза цитокинов клетками эпителия бронхов у больных 1-й и 2-й групп (M+m)

\begin{tabular}{|c|c|c|c|c|c|}
\hline \multirow[b]{2}{*}{$\begin{array}{l}\text { Пока- } \\
\text { затель } \\
\text { (пг/мл) }\end{array}$} & \multirow[b]{2}{*}{ Группа } & \multirow[b]{2}{*}{$\begin{array}{c}\text { Стат. } \\
\text { показ. }\end{array}$} & \multicolumn{3}{|c|}{ Этапы витрального эксперимента } \\
\hline & & & $\begin{array}{c}\text { Опыт } 1 \\
\text { (введение в куль- } \\
\text { туральную среду } \\
\text { взвеси LPS- } \\
\text { индуцированных } \\
\text { автологичных мо- } \\
\text { нонуклеарных лей- } \\
\text { коцитов } \rightarrow \text { уро- } \\
\text { вень цитокина в } \\
\text { культуральной } \\
\text { среде) }\end{array}$ & $\begin{array}{c}\text { Опыт } 2 \\
\text { (преинкубация моно- } \\
\text { нуклеаров с остеопроте- } \\
\text { герином (20000 пг/мл } \\
\text { среды) } \rightarrow \text { отмывание } \\
\text { клеток } \rightarrow \text { в культураль- } \\
\text { ную среду) }\end{array}$ & $\begin{array}{c}\text { Опыт } 3 \\
\text { (преинкубация моно- } \\
\text { нуклеаров с остео- } \\
\text { протегерином (20000 } \\
\text { пг/мл среды) } \rightarrow \text { от- } \\
\text { мывание клеток } \rightarrow \\
\text { инкубация клеток с } \\
\text { липофлавоном } \rightarrow \\
\text { отмывание клеток } \rightarrow \\
\text { в культуральную } \\
\text { среду) }\end{array}$ \\
\hline \multirow{2}{*}{ IL-1 $\beta$} & $\begin{array}{c}\text { 1-я } \\
\text { группа }\end{array}$ & $\begin{array}{c}\mathrm{M} \pm \mathrm{m} \\
\mathrm{n} \\
\mathrm{p} \\
\mathrm{p}_{1} \\
\mathrm{p}_{2}\end{array}$ & $\begin{array}{c}20,55 \pm 0,77 \\
26 \\
- \\
- \\
-\end{array}$ & $\begin{array}{c}28,27 \pm 1,05 \\
26 \\
- \\
<0,001 \\
-\end{array}$ & $\begin{array}{c}22,60 \pm 1,02 \\
26 \\
- \\
<0,2 \\
<0,001\end{array}$ \\
\hline & $\begin{array}{c}\text { 2-я } \\
\text { группа }\end{array}$ & $\begin{array}{c}\mathrm{M} \pm \mathrm{m} \\
\mathrm{n} \\
\mathrm{p} \\
\mathrm{p}_{1} \\
\mathrm{p}_{2}\end{array}$ & $\begin{array}{c}27,35 \pm 0,88 \\
28 \\
<0,001 \\
- \\
-\end{array}$ & $\begin{array}{c}33,96 \pm 1,34 \\
28 \\
<0,001 \\
<0,001 \\
-\end{array}$ & $\begin{array}{c}29,33 \pm 1,03 \\
28 \\
<0,001 \\
<0,2 \\
<0,01\end{array}$ \\
\hline \multirow{2}{*}{ IL-4 } & $\begin{array}{c}\text { 1-я } \\
\text { группа }\end{array}$ & $\begin{array}{c}\mathrm{M} \pm \mathrm{m} \\
\mathrm{n} \\
\mathrm{p} \\
\mathrm{p}_{1} \\
\mathrm{p}_{2} \\
\end{array}$ & $\begin{array}{c}5,01 \pm 0,20 \\
26 \\
- \\
- \\
-\end{array}$ & $\begin{array}{c}\text { В диапазоне чувстви- } \\
\text { тельности тест-системы } \\
\text { определялся в } 12 \text { из } 26 \\
\text { проб }\end{array}$ & $\begin{array}{c}3,10 \pm 0,14 \\
26 \\
- \\
<0,001 \\
-\end{array}$ \\
\hline & $\begin{array}{c}\text { 2-я } \\
\text { группа }\end{array}$ & $\begin{array}{c}\mathrm{M} \pm \mathrm{m} \\
\mathrm{n} \\
\mathrm{p} \\
\mathrm{p}_{1} \\
\mathrm{p}_{2}\end{array}$ & $\begin{array}{c}3,92 \pm 0,18 \\
28 \\
<0,001 \\
- \\
-\end{array}$ & $\begin{array}{c}\text { В диапазоне чувстви- } \\
\text { тельности тест-системы } \\
\text { определялся в } 9 \text { из } 28 \\
\text { проб }\end{array}$ & $\begin{array}{c}2,23 \pm 0,17 \\
28 \\
<0,001 \\
<0,001 \\
-\end{array}$ \\
\hline \multirow{2}{*}{ TNF- $\alpha$} & $\begin{array}{c}\text { 1-я } \\
\text { группа }\end{array}$ & $\begin{array}{c}\mathrm{M} \pm \mathrm{m} \\
\mathrm{n} \\
\mathrm{p} \\
\mathrm{p}_{1} \\
\mathrm{p}_{2}\end{array}$ & $\begin{array}{c}18,57 \pm 0,78 \\
26 \\
- \\
- \\
-\end{array}$ & $\begin{array}{c}31,31 \pm 1,22 \\
26 \\
- \\
<0,001 \\
-\end{array}$ & $\begin{array}{c}28,83 \pm 1,31 \\
26 \\
- \\
<0,001 \\
<0,2\end{array}$ \\
\hline & $\begin{array}{c}\text { 2-я } \\
\text { группа }\end{array}$ & $\begin{array}{c}\mathrm{M} \pm \mathrm{m} \\
\mathrm{n} \\
\mathrm{p} \\
\mathrm{p}_{1} \\
\mathrm{p}_{2}\end{array}$ & $\begin{array}{c}25,68 \pm 0,93 \\
28 \\
<0,001 \\
- \\
-\end{array}$ & $\begin{array}{c}34,07 \pm 1,73 \\
28 \\
<0,2 \\
<0,001 \\
-\end{array}$ & $\begin{array}{c}28,74 \pm 1,03 \\
28 \\
<0,5 \\
<0,001 \\
<0,01\end{array}$ \\
\hline \multirow{2}{*}{ TGF- $\beta 1$} & $\begin{array}{c}\text { 1-я } \\
\text { группа }\end{array}$ & $\begin{array}{c}\mathrm{M} \pm \mathrm{m} \\
\mathrm{n} \\
\mathrm{p} \\
\mathrm{p}_{1} \\
\mathrm{p}_{2}\end{array}$ & $\begin{array}{c}55,11 \pm 1,61 \\
26 \\
- \\
- \\
-\end{array}$ & $\begin{array}{c}58,13 \pm 2,03 \\
26 \\
- \\
<0,5 \\
-\end{array}$ & $\begin{array}{c}48,77 \pm 2,01 \\
26 \\
- \\
<0,02 \\
<0,01\end{array}$ \\
\hline & $\begin{array}{c}\text { 2-я } \\
\text { группа }\end{array}$ & $\begin{array}{c}\mathrm{M} \pm \mathrm{m} \\
\mathrm{n} \\
\mathrm{p} \\
\mathrm{p}_{1} \\
\mathrm{p}_{2}\end{array}$ & $\begin{array}{c}59,35 \pm 2,56 \\
28 \\
<0,2 \\
- \\
-\end{array}$ & $\begin{array}{c}61,25 \pm 2,51 \\
28 \\
<0,5 \\
>0,5 \\
-\end{array}$ & $\begin{array}{c}52,82 \pm 2,73 \\
28 \\
<0,5 \\
<0,1 \\
<0,05\end{array}$ \\
\hline
\end{tabular}

Примечание. $\mathrm{p}$ - достоверность различий, высчитанная в сравнении с соответствующим этапом эксперимента у больных 1-й группы, $\mathrm{p}_{1}$ - достоверность различий, высчитанная в сравнении с опытом 1 в той же группе больных, $\mathrm{p}_{2}-$ достоверность различий, высчитанная в сравнении с опытом 2 в той же группе больных 
Ранее повышение уровня остеопротегерина в индуцированной мокроте у больных ХОЗЛ выявлено То М. и соавт. (2011) [8].

Нами установлено, что под влиянием преинкубации LPS-индуцированных автологичных мононуклеарных лейкоцитов с 20000 пг/мл среды человеческого остеопротегерина (опыт 2) уровень IL-1 $\beta$ в культуральной среде по завершении культивации возрастает (в сравнении с опытом 1) у больных 1-й и 2-й групп соответственно на $37,6 \%$ и $\left.24,2 \%, \mathrm{p}_{1}<0,001\right)$, что свидетельствует о возможности остеопротегеринзависимого возрастания провоспалительного (по уровню IL-1 $\beta$ ) цитокинового потенциала у больных ХОЗЛ. В опыте 3 нами установлено, что под влиянием инкубации клеток с липофлавоном уровень IL-1 $\beta$ в супернатанте культуры клеток бронхиального эпителия у больных как 1-й, так и 2-й групп снижается соответственно на $20,1 \%\left(\mathrm{p}_{2}<0,001\right)$ и на $13,6 \%\left(\mathrm{p}_{2}<0,01\right)$.

В опыте 1 уровень IL-4 в супернатанте культуральной среды культуры клеток бронхиального эпителия у больных 2-й группы статистически значимо ниже, чем у больных 1-й группы.

Таким образом, течение ХОЗЛ у лиц, перенесших ТБ легких и с достоверно более высоким уровнем остеопротегерина в индуцированной мокроте характеризуется снижением уровня цитокина IL-4 с антивоспалительной активностью. Под влиянием преинкубации LPS-индуцированных автологичных мононуклеарных лейкоцитов с 20000 пг/мл среды человеческого остеопротегерина (опыт 2) исследованный показатель снижается настолько, что в диапазоне чувствительности тест-системы определяется лишь в части проб. В опыте 3 выявлено, что инкубация клеток с липофлавоном частично "отменяет" ингибирующее влияние остеопротегерина на синтез цитокина IL-4 клетками эпителия бронхов у больных как 1-й, так и 2-й групп.

Уровень TNF- $\alpha$ в супернатанте культуральной среды культуры клеток бронхиального эпителия у больных 2-й группы (в опыте 2) статистически значимо выше, чем у больных 1-й группы. В опыте 2 исследованный показатель у больных как 1-й, так и 2-й групп существенно возрастает (в сравнении с опытом 2) соответственно на $75,6 \%$ и 43,9 \% $\left(\mathrm{p}_{1}<0,001\right)$, что документирует наличие у больных ХОЗЛ остеопротегеринзависимого мононуклеароопосредованного механизма синтеза TNF- $\alpha$ клетками эпителия бронхов. В опыте 3 выявлено, что инкубация клеток с липофлавоном частично "отменяет" ингибирующее влияние остеопротегерина на синтез провоспалительного цитокина TNF- $\alpha$ клетками эпителия бронхов только у больных 2-й группы: в сравнении с опытом 2 исследованный показатель снижается на 15,6 \% $\left(\mathrm{p}_{2}<0,01\right)$.

Нами также установлено, что в сравнении с опытом 1 в опыте 2 синтез активной формы TGF$\beta 1$ существенно не меняется у больных как 1-й, так и 2-й групп. В опыте 3 выявлено, что инкуба- ция клеток с липофлавоном способствует статистически значимому снижению синтеза активной формы TGF- $\beta 1$ клетками эпителия бронхов у больных как 1-й, так и 2-й группы: в сравнении с опытом 2 исследованный показатель снижается соответственно на $16,1 \%\left(\mathrm{p}_{2}<0,01\right)$ и на $13,8 \%$ $\left(\mathrm{p}_{2}<0,05\right)$.

\section{Выводы}

1. У больных хроническим обструктивным заболеванием легких I-II стадии, прежде всего - у больных хроническим обструктивным заболевание легких, перенесших туберкулез легких и с достоверно более высоким уровнем остеопротегерина в индуцированной мокроте выявлена возможность липофлавонопосредованной коррекции остеопротегеринзависимого лейкоцитоопосредованного синтеза клетками бронхиального эпителия уровня провоспалительных цитокинов IL-1 $\beta$ и TNF- $\alpha$ (только у больных 2-й группы), цитокина IL-4 и активной формы TGF- $\beta 1$.

2. Патофизиологически обоснована целесообразность местного (ингаляции, эндобронхиальное введение) использования липофлавона для коррекции дисбаланса цитокинового гомеостаза на регионарном (ткани бронхов) уровне у больных хроническим обструктивным заболеванием легких, перенесших туберкулез легких и с повышенным уровнем остеопротегерина в индуцированной мокроте.

Перспективы дальнейших исследований. Усовершенствование методов патогенетического лечения хронического обструктивного заболевания легких у больных, перенесших туберкулез легких.

\section{Литература}

1. Дудниченко А.С. Липосомальные лекарственные препараты в эксперименте и клинике / А.С. Дудниченко, Ю.М. Краснопольский, В.И. Швец. - Харьков: Изд. группа "РАКаравелла", 2001. - 144 с.

2. Лимарев В.А. Влияние фосфатидилхолиновых липосом (липина) на липополисахаридиндуцированную лимфоидную (лейкоцитарную) регуляцию синтеза цитокинов клетками эпителия бронхов у больных с сочетанным течением ХОЗЛ и анемического синдрома у лиц, перенесших туберкулез / В.А. Лимарев, М.М. Гришин // Таврич. мед.-биол. вестник. 2011. - Т. 14, № 1 (53). - С. 92-97.

3. Марголис Л.Б. Липосомы / Л.Б. Марголис, Л.Д. Бергельсон. - М.: Изд. дом "Русский врач", 2001. - 396 с.

4. Тімченко О.Б. Клініко-імунологічне обгрунтування комплексної терапії обструктивних захворювань легенів у хворих, котрі перенесли туберкульоз легенів: автореф. дис. на здобуття наук. ступеня канд. мед. наук: спец. 14.01.27 «Пульмонологія»/ О.Б. Тімченко. - Ялта, 2008. - 121 с.

5. Chronic obstructive pulmonary disease and intake of catechins, flavonols, and flavones: the 
MORGEN Study / C. Tabak, C. Ilja, C.W. Arts [et al.] // Am. J. Respir. Crit. Care Med. - 2001. Vol. 164. - P. 61-64.

6. Crowe I.H. Liposomes: preparation, characterization and preservation / I.H. Crowe, L.M. Crowe, D. Chapman // Science. - 1998. - Vol. 223, № 5. - P. 701-703.

7. Inhibition of anti-Tuberculosis $\mathrm{T}$ lymphocyte function with Tumor Necrosis Factor antagonists / H. Hamdi, X. Mariette, V. Godot [et al.] // Arthritis Res. Ther. - 2006. - Vol. 19, № 8. P. 114.

8. Osteoprotegerin in sputum is a potential biomarker in COPD / M. To, K. Ito, P.M. Ausin [et. al.] // CHEST. - 2011. - Vol. 140, № 1. - P. 76-83.
9. Oxidant stress and chronic obstructive pulmonary disease / J.E. Repine, A. Bast, I. Lankhorst [et al.] // Am. J. Respir. Crit. Care. Med. - 2003. Vol. 156. - P. 341-357.

10. Tumor-necrosis-factor blockers: differential effects on mycobacterial immunity / O.Y. Saliu, C. Sofer, D.S. Stein [et al.] // J. Infect. Dis. 2006. - Vol. 15, № 194. - P. 486-492.

11. Westphal O. Bacterial endotoxins: chemical and clinical aspects /O. Westphol // Weinheim. 1984. - P. 1-10.

\section{ВПЛИВ ЛІПОФЛАВОНУ НА ОСТЕОПРОТЕГЕРИНОПОСЕРЕДКОВАНУ ЛІМФОЇДНУ (ЛЕЙКОЦИТАРНУ) РЕГУЛЯЦІЮ СИНТЕЗУ ЦИТОКІНІВ КЛІТИНАМИ ЕПІТЕЛІЮ БРОНХІВ У ХВОРИХ НА ХРОНІЧНІ ОБСТРУКТИВНІ ЗАХВОРЮВАННЯ ЛЕГЕНЬ, ЯКІ ПЕРЕНЕСЛИ ТУБЕРКУЛЬОЗ ЛЕГЕНЬ}

\section{Н.В. Обухова}

Резюме. У хворих на хронічні обструктивні захворювання легень (ХОЗЛ), які перенесли туберкульоз (ТБ) легень, вивчені регіонарний (в індукованому мокротинні) рівень остеопротегерину, а також модулюючий вплив ліпофлавону на остеопротегеринопосередкованну лімфоїдну (лейкоцитарну) регуляцію синтезу цитокінів клітинами епітелію бронхів.

Установлено, що у хворих на ХОЗЛ І-ІІ стадії, перш за все, які перенесли туберкульоз легень та 3 вірогідно більш високим рівнем остеопротегерину в індукованому мокротинні, виявлена можливість ліпофлавонопосередкованої корекції остеопротегеринзалежного лейкоцитоопосередкованого синтезу клітинами бронхіального епітелію рівня прозапальних цитокінів IL-1 $\beta$ і TNF- $\alpha$, цитокіну IL-4 і активної форми TGF- $\beta 1$. Указані факти розцінюються як патофізіологічне обгрунтування доцільності місцевого (інгаляції, ендобронхіальне уведення) використання у подібних хворих ліпофлавону для корекції дисбалансу цитокінового гомеостазу на регіонарному (тканини бронхів) рівні.

Ключові слова: остеопротегерин, цитокіни, бронхіальний епітелій, хронічне обструктивне захворювання легень, туберкульоз легень.

\section{INFLUENCE OF LIPOFLAVON ON OSTEOPROTEGERIN-MEDIATED LYMPHOID - (LEUKOCYTIC) REGULATION OF CYTOKINE SYNTHESIS BY THE CELLS OF THE BRONCHIAL EPITHELIUM IN PATIENTS WITH COPD, WHO HAVE SUFFERED FROM PULMONARY TUBERCULOSIS}

\section{N.V. Obukhova}

Abstract. The regional (in induced sputum) level of osteoprotegerin and also a modulating influence of lipoflavon on osteoprotegerin-mediated lymphoid (leukocytic) regulation of cytokine synthesis by cells of the bronchial epithelium in patients with chronic obstructive pulmonary disease (COPD), suffering from pulmonary tuberculosis have been studied. It has been established that in patients with COPD of the $\mathrm{I}^{\text {st }}$-II ${ }^{\text {nd }}$ stage; first of all, - in the patients, who have suffered from PT and with a significantly higher level of osteoprotegerin in induced sputum a possibility of a lipoflavon-mediated correction of osteoprotegerin-dependent leukocytic-mediated synthesis by cells of the bronchial epithelium of the level of proinflammatory cytokines IL- $1 \beta$ and TNF- $\alpha$, cytokine IL- 4 and active form TGF- $\beta 1$ has been detected. The facts in question are estimated as a pathophysiological substantiation of the expediency of a local (inhalations, endobronchial introduction) use of lipoflavon in such patients for the purpose of correcting an imbalance of cytokine homeostasis at the regional (bronchial tissues) level.

Key words: osteoprotegerin, cytokines, bronchial epithelium, chronic obstructive pulmonary disease, pulmonary tuberculosis.

SE "State Medical University" (Donetsk)

Рецензент - проф. Л.Д. Тодоріко

Buk. Med. Herald. - 2013. - Vol. 17, № 1 (65). - P. 71-75

Надійшла до редакції 24.12.2012 року

(C) Н.В. Обухова, 2013 